\title{
Biological differences and unilateral cross-protection between biotypes of Cowpea aphid-borne mosaic virus ${ }^{1}$
}

\author{
Diferenças biológicas e proteção cruzada unilateral entre biótipos de Cowpea aphid- \\ borne mosaic vírus
}

\author{
Laianny Morais Maia ${ }^{2 *}$, José Albersio de Araujo Lima ${ }^{2}$, Aline Kelly Queiroz do Nascimento ${ }^{2}$ and Francisco \\ de Assis Câmara Rabelo Filho ${ }^{2}$
}

\begin{abstract}
Passion fruit (Passiflora edulis) and cowpea (Vigna unguiculata) are two agricultural crops of considerable economic importance in Northeastern Brazil. Fruit woodiness caused by isolates of Cowpea aphid-borne mosaic virus biotype $\mathrm{P}(\mathrm{CABMV}-\mathrm{P})$ is the most important virus disease that occurs on passion fruit in Brazil and the biotype cowpea $(\mathrm{CABMV}-\mathrm{C})$ is responsible for the most common and important virus disease of cowpea in Northeastern Brazil. The objective of the present research was to determine the biological relationships between isolates of biotype CABMV-C obtained from cowpea (CABMV-CFor and CABMV-CBv) and isolates of biotype CABMV-P obtained from passion fruit (CABMV-PMild and CABMV-PSevere) in common hosts. In host range studies involving 25 plant species only Canavalia ensiformis and Macroptilium lathyroides were shown to be common systemic hosts for all virus isolates. Cross protection studies were developed between CABMV-PMild and CABMV-PSevere in passion fruit and between CABMV-PSevere and CABMV-CFor in C. ensiformis. Unilateral cross protection was detected between CABMVPSevere and CABMV-CFor in $C$. ensiformis, but CABMV-PMild did not cross protect passion fruit against CABMVPSevere.
\end{abstract}

Key words: Potyvirus. Partial cross protection. Passion fruit woodiness.

\begin{abstract}
RESUMO - Maracujazeiro (Passiflora edulis) e feijoeiro caupi (Vigna unguiculata) são duas culturas economicamente importante para o Nordeste do Brasil. O endurecimento dos frutos causado por isolados de Cowpea aphid-borne mosaic virus biótipo P (CABMV-P) é a virose mais importante que ocorre no maracujazeiro no Brasil e o biótipo caupi (CABMV-C) é responsável pela virose mais comum e importante que afeta o feijoeiro caupi. O objetivo desta pesquisa foi determinar as relações biológicas entre isolados do biótipo CABMV-C obtido de feijoeiro caupi (CABMV-CFor e CABMV-CBv) e isolados do biótipo CABMV-P obtidos de maracujazeiro (CABMV-PFraco e CABMV-PSevera) em hospedeiros comuns. Em estudos de gama de plantas hospedeiros, envolvendo 25 espécies de plantas, somente Canavalia ensiformis e Macroptilium lathyroides mostraram ser hospedeiros sistêmicos comuns a todos os isolados virais. Estudos de proteção cruzada foram desenvolvidos entre CABMV-PFraco e CABMV-PSevero em maracujazeiro e CABMV-PSevero e CABMV-CFor em C. ensiformis. Proteção cruzada unilateral foi detectada entre CABMV-PSevero e CABMV-CFor em C. ensiformes, mas CABMV-PFraco não protegeu maracujazeiro contra o CABMV-PSevero.
\end{abstract}

Palavras-chave: Potyvirus. Proteção cruzada parcial. Passion fruit woodiness.

\footnotetext{
DOI: $10.5935 / 1806-6690.20170036$

*Autor para correspondência

Recebido para publicação em 18/09/2015 aprovado em 13/06/2016

${ }^{1}$ Parte da Dissertação do primeiro autor apresentada no Programa de Pós-Graduação em Agronomia/Fitotecnia/CCA/UFC

${ }^{2}$ Departamento de Fitotecnia, Centro de Ciência Agrárias, Universidade Federal do Ceara, Av. Mister Hull, 2977, Bloco 806, Campus do Pici,

Fortaleza-CE, Brasil,60.356-000, laiannymorais@hotmail.com, albersio@ufc.br, alynekellly@yahoo.com.br, camara.filho@hotmail.com
} 


\section{INTRODUCTION}

The Northeast of Brazil has a great potential for production of cowpea [Vigna unguiculata (L.) Walp. subsp. unguiculata] and several tropical fruit crops including passion fruit (Passiflora edulis Sims) (LIMA et al., 2015). Cowpea is a leguminous food of great importance for small growers from Northeastern Brazil and the State of Ceará is one of the highest producers in Brazil (SIDRA, 2015). Many factors can affect the productivity of cowpea, especially the virus diseases which have been responsible for great economic losses, since the crop has economical and social relevance for the region. More than 20 viruses can naturally infect cowpea around the world (LIMA, 2015), but Cowpea aphid-borne mosaic virus (CABMV), family Potyviridae, genus Potyvirus, which was first isolated in the State of Ceará in 1981 is considered the most important virus species that infect cowpea in Northeastern Brazil (LIMA, 2015).

Passion fruit is a fruit crop cultured in Brazil, that is also affected by virus diseases which have adversely affected its production and expansion (FISCHER; KIMATI; RESENDE, 2005; NICOLINI et al., 2012). Several virus species have already been identified causing disease on passion fruit in Brazil and species from the genus Potyvirus have been considered to be responsible for the most important problems (LIMA et al., 2015; MACIEL et al., 2009). A virus isolated from naturally infected passion fruit orchards in the State of Ceará was identified as Passion fruit woodiness virus (PWV), from genus Potyvirus based on its biological and serological properties (LIMA et al., 2015). The following other virus species were also identified in passion fruit in Brazil: Cucumber mosaic virus (CMV), genus Cucumovirus; Passion fruit yellow mosaic virus (PFYMV) family Tymoviridae, genus Tymovirus; a species from the genus Rhabdovirus and another from the genus Begomovirus (LIMA et al., 2015).

Based on biological, serological and mainly molecular results, it was proposed that the CABMV isolates which occur in Northeast of Brazil should be reclassified into Biotype CABMV-C (C for Cowpea) to include isolates obtained from cowpea that do not infect passion fruit, and biotype CABMV-P ( $\mathrm{P}$ for Passion fruit) to include the virus isolates obtained from passion fruit in Brazil that do not infect cowpea (LIMA et al., 2015; NASCIMENTO, 2014).

The present research had the objective of evaluating biological interaction between CABMVPMild and CABMV-PSevere in passion fruit and between CABMV-PSevere and CABMV-CFor in a common host to define the possibility of using a mild strain to cross protect against severe strains of the causal agent of passion fruit woodiness and define the biological differences between the biotype $\mathrm{C}$ and biotype $\mathrm{P}$ by host range studies.

\section{MATERIAL AND METHODS}

\section{Source of Viruses}

The virus isolates used in the present research belong to the Active Collection of Plant Viruses from the Plant Virus Laboratory at the Federal University of Ceará (LabVV/UFC) and represent important virus species pertinent to the agricultural business from the State. Two isolates of CABMV originally obtained from naturally infected cowpea in Fortaleza (CABMV-CFor), causing mosaic and in Bela Vista farmer (CABMV-CBv) causing severe mosaic and leaf bubbles, both in the State of Ceará, and two isolates of CABMV-P, one obtained from naturally infected passion fruit orchards with severe symptoms in the State of Ceará (CABMV-PSevere) and an isolate that caused mild symptoms (CABMV-PMild) in passion fruit obtained in the State of Pernambuco (LIMA et al., 2015).

The virus isolates were maintained by mechanical inoculation in cowpea (CABMV-CBv and CABMVCFor) and in passion fruit plants (CABMV-PSevere and CABMV-PMild) at greenhouse conditions. For mechanical inoculations, leaf samples from respective infected plants were ground in the presence of potassium phosphate buffer $0.05 \mathrm{M}, \mathrm{pH} 7.5$ in the proportion of $1: 2(\mathrm{w} / \mathrm{v})$ and the extracts were strained through double layers cheesecloth. A small quantity of carborundum (400 meshes) was added to the plant extracts with the virus and the mechanical inoculation was performed by rubbing the plant leaves with a piece of double cheesecloth embedded with the extracts containing the virus. All inoculated and no inoculated plants were maintained in a greenhouse.

\section{Host Range Studies}

A total of 25 plant species from the botanical families Amaranthaceae, Brassicaceae, Curcubitaceae, Fabaceae, Laminaceae, Passifloraceae, Pedaliaceae and Solanaceae (Table 1) were used to comparatively evaluate the partial host range for the virus isolates. The plant species and cultivars were raised under greenhouse conditions, using four plants per pot with sterile fertilized soil for each virus isolate and a pot with four non inoculated plants was maintained as a control for each plant species/cultivar.

The plants were mechanically inoculated with each virus isolate: Amaranthaceae: Chenopodium amaranticolor Coste \& A. Reyn. C. quinoa Willd and Gomphrena globosa L.; Brassicaceae: Brassica juncea 
L.; Curcubitaceae: Cucumis sativum L.; Fabaceae: Arachis hypogaea L., Canavalia ensiformis (L.) DC, Dolichos lablab L., Glycine max (L.) Merrill, Leucaena leucocephala (Lam.) de Wit., Macroptilium atropurpureum (DC) Urb., M. lathyroides (L.) Urb., Phaseolus vulgaris L. 'Vermelho' and 'Carioquinha'; Pisum sativum L., Vigna mungo L., V. unguiculata (L.) Walp sub-especies unguiculata 'Adzuki', 'CE 566', 'CE 113', 'CE 189', 'CE 524', 'Costela-de-vaca', 'Lizão', 'Macaibo' 'Manteigão', 'Paulista-PB', 'Pingo-de-ouro', 'Paulistinha', 'Pitiuba' 'Sempre-verde', and 'Setentão'; Lamiaceae: Ocimum basilicum L. 'Lemoncio', 'Basilicão vermelho' and 'Toscano'; Passifloraceae: Passiflora edulis Sims cv. Macae, $P$. setacea D.C., P. cincinnata Mast., P. Gibertii N. E. Brown; Pedaliaceae: Sesamum indicum L.; Solanaceae: Nicotiana benthamiana Domin, N. debney Domin and Petunia axillaris (Lam.) Britton, Sterns and Poggenb (Table 1).

All the inoculated plants were maintained at greenhouse conditions and the appearance of symptoms was followed daily. After 15 days, the plants were tested by plate trapped enzyme linked immune absorbent assay (PTA-ELISA) and those that showed negative results were re-inoculated.

\section{Biological Interactions among Isolates of Cowpea aphid-borne mosaic virus Obtained from Cowpea and from Passion Fruit}

The interaction between the mild isolate CABMVPMild and the severe isolate CABMV-PSevere obtained from naturally infected passion fruit was evaluated in young passion fruit plants in greenhouse conditions. To evaluate the possibility that CABMV-PMild protects passion fruit against CABMV-PSevere, the following treatments were developed: A-Passion fruit plants inoculated with CABMV-PMild; B-Passion fruit plants inoculated with CABMV-PSevere; C-Passion fruit plants inoculated with CABMV-PMild and after 15 days inoculated with CABMV-PSevere; and D-No inoculated passion fruit plants maintained as control. Twenty days after the second virus inoculations, all 28 inoculated plants were tested by PTA-ELISA against antiserum for CABMV-PSevere produced in the (LabVV/UFC) which also reacts with CABMV-PMild. Additionally, the possible presence of CABMV-PSevere in the doubly inoculated plants from treatment $\mathrm{C}$ was evaluated by inoculating extracts from each of those doubly inoculated plants into healthy $C$. ensiformis plants which demonstrated previously to be infected only with CABMV-PSevere (NASCIMENTO, 2014).

The possible biological interaction between CABMV-CFor and CABMV-PSevere was also evaluated in plants of $C$. ensiformis, a common host for both virus isolates. The experiment consisted of the following treatments: A-Plants of $C$. ensiformis inoculated with CABMV-CFor; B-Plants of $C$. ensiformis inoculated with CABMV-PSevere; C-Plants of $C$. ensiformis inoculated with CABMV-CFor and 15 days later re-inoculated with CABMV-PSevere; D-Plants of $C$. ensiformis inoculated with CABMV-PSevere and 15 days later re-inoculated with CABMV-CFor, and E-No inoculated C. ensiformis plants maintained as control.

All the plants were observed for symptom development and tested by PTA-ELISA against the respective virus antiserum. Additionally, the possible presence of CABMV-PSevere in the doubly inoculated plants from treatment $\mathrm{C}$ was evaluated by inoculation to healthy passion fruit plants, while the possible presence of CABMV-CF or in the double inoculated plants from treatment $\mathrm{D}$ was also evaluated by inoculation in healthy cowpea plants. Healthy plants of $C$. ensiformis also were inoculated with the extracts used for the challenge inoculations in treatments $C$ and $D$ to verify infectivity of the inocula.

\section{RESULTS AND DISCUSSION}

\section{Source of Virus}

The virus isolates were maintained in vivo conditions by periodic mechanical inoculations to healthy young plants of their respective natural hosts: cowpea (CABMV-CFor and CABMV-CBv) and passion fruit (CABMV-PMild and CABMV-PSevere). CABMV-PMild and CABMV-PSevere infected and caused mosaic symptoms in passion fruit approximately 15 days after mechanical inoculation, but the symptoms induced by CABMV-PSevere were more severe than those caused by CABMV-PMild (Figure 1). On the other hand, the cowpea plants systemically infected with CABMV-CBv or with CABMV-CFor presented similar symptoms of mosaic, bubbles and leaf deformations (Figure $1 \mathrm{C}$ and D).

\section{Comparative Host Range Studies of CABMV Isolates}

The symptom reactions in different plant species infected with the viruses confirmed by PT-ELISA demonstrated biological differences among the virus isolates obtained from cowpea and those obtained from passion fruit (Table 1). All isolates of CABMV-C and CABMV-P caused local lesions in C. amaranticolor and in $C$. quinoa, but did not infect $G$. globosa. The plant species from the Fabaceae family $C$. ensiformis, $M$. lathyroides and $V$. unguiculata were systemically infected by CABMV-CBv and CABMV-CFort, obtained 
Figure 1 - Passion fruit (Passiflora edulis) and cowpea (Vigna unguiculata) systemically infected with isolates of Cowpea aphid-borne mosaic virus (CABMV). A) Passion fruit infected with CABMV-PMild presenting mild symptoms, B) Passion fruit infected with CABMV-PSevere showing severe symptoms, C) Cowpea infected with CABMV-CFor and D) Cowpea infected with CABMV-CBv

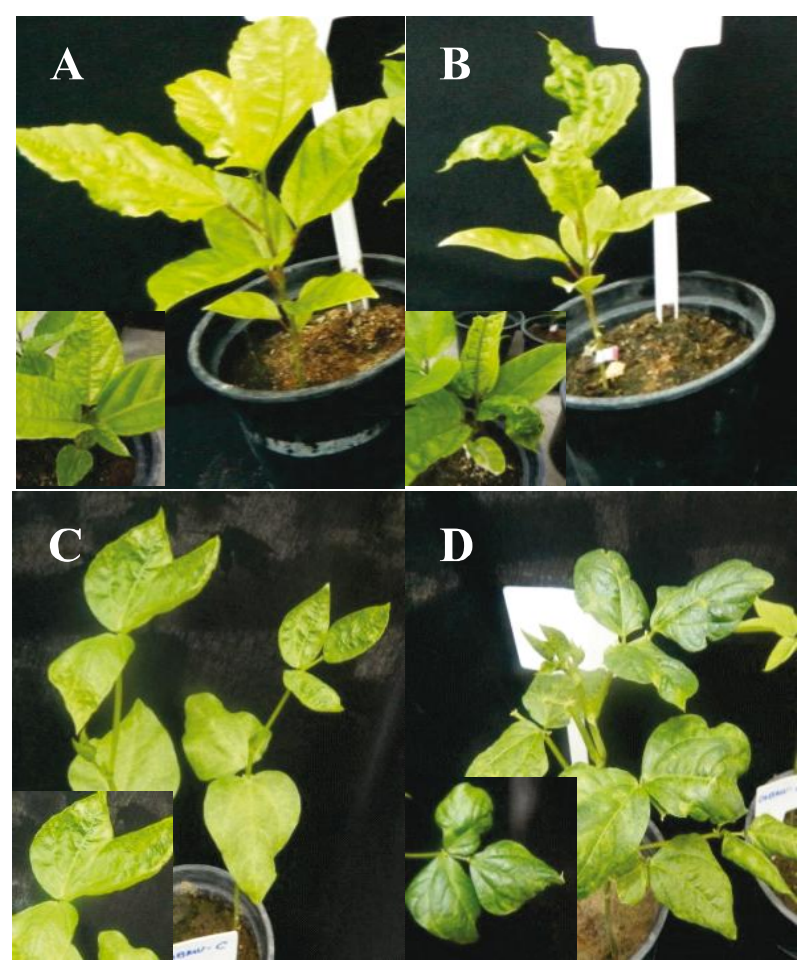

from cowpea, causing severe symptoms, but CABMVPSevere and CABMV-PMild obtained from passion fruit did not infect cowpea. Macroptilium lathyroides was also infected by CABMV-PSevere and CABMVPMild, but C.ensiformis was only infected by CABMVPSevere (Table 1). On the other hand, all CABMV$\mathrm{C}$ and CABMV-P isolates infected systemically $S$. indicum causing local clorotic lesions followed by mosaic (Table 1), indicating that it could be a natural host for those virus isolates in the field. One CABMV$\mathrm{C}$ isolate was obtained from $S$. indicum with symptoms of mosaic and leaf distortions in experimental cowpea fields in the State of Ceará and the CABMV-C isolate infected several cowpea cultivars (LIMA et al., 1991). Sreenivasulu et al. (1994) also isolated a virus from the genus Potyvirus from S. indicum in Georgia, which also infected cowpea.

The host range studies demonstrated similarities among the CABMV-C isolates obtained from cowpea, and also between the isolates obtained from passion fruit
(CABMV-P), but several differences were observed among the isolates obtained from cowpea (CABMV-C) compared with the isolates obtained from passion fruit (CABMV$\mathrm{P})$. The isolates of CABMV-P did not infect more than 27 cowpea varieties neither the CABMV-C isolates infected the following plant species from the family Passifloraceae: Passiflora edulis, P. edulis 'Macae', P. setacea, $P$. cincinnata and P. gibertii (Table 1). According to Bock (1973) there are several distinct CABMV strains which could be differentiated by their biological properties and according to Rodrigues et al.(2015), isolates of CABMV$\mathrm{P}$ obtained from infecting yellow passion fruit in four Brazilian States infected M. atropurpureum, but did not infect cowpea.

These host range studies confirmed some biological differences among isolates of CABMV-C and CABMV-P, showing that they can be differentiated according to their biological properties and that CABMV-C isolates do not infect passion fruit and CABMV-P isolates do not infect cowpea cultivars. On the other hand, it was demonstrated that CABMV-CBv and CABMV-CFor cause severe mosaic in several cowpea genotypes, especially in cv. Pitiuba an important cultivar produced in the Northeastern Brazil (Table 1), which agree with the results of previous studies (NASCIMENTO, 2014). According to Taiwo and Akinjoguna (2006), earlier virus infection, especially with CABMV in cowpea, caused the greatest losses in crop production.

Although Nascimento et al. (2006) demonstrated that CABMV isolates obtained from passion fruit caused systemic infections in cowpea, neither CABMV-PSevere or CABMV-PMild infected cowpea in the present study (Table 1). Similarly, Nascimento (2014) and Rodrigues et al. (2015) demonstrated that isolates of CABMV-Pobtained from passion fruit did not infect cowpea. Bock (1973) reported the absence of symptoms in cowpea inoculated with virus isolates from the genus Potyvirus obtained from passion fruit. The CABMV-C isolates obtained from cowpea did not infect passion which is strong evidence that the causal agent of passion fruit woodiness does not infect cowpea (BARROS et al., 2013; NASCIMENTO, 2014; LIMA et al., 2015).

All species from the family Passifloraceae evaluated were systemically infected by all isolates of CABMV-P, including CABMV-PMild and CABMVPSevere, and some isolates obtained from passion fruit from different regions in the State of Ceará (CABMVPGua, CABMV-PSb and CABMV-PUba). However, neither one of $\mathrm{CABMV}-\mathrm{C}$ isolates obtained from cowpea, including $\mathrm{CABMV-CBv}$ and $\mathrm{CABMV}-\mathrm{CF}$ ort infected any of more than 40 inoculated plants from the genus Passiflora. 
Table 1 - Symptoms and serological results of different plant species and cultivars mechanically inoculated with virus isolates of Cowpea aphid-borne mosaic virus (CABMV) obtained from Passiflora edulis (CABMV-PMild and CABMV-PSevere) and from Vigna unguiculata (CABMV-CBv and CABMV-CFor)

\begin{tabular}{|c|c|c|c|c|c|c|c|c|}
\hline \multirow{2}{*}{ Family/Plant species/Cultivar } & \multicolumn{2}{|c|}{ CABMV-PSevere } & \multicolumn{2}{|c|}{ CABMV-PMild } & \multicolumn{2}{|c|}{ CABMV-CBv } & \multicolumn{2}{|c|}{ CABMV-CFor } \\
\hline & Sympt.* & ELISA & Sympt.* & ELISA & Sympt.* & ELISA & Sympt.* & ELISA \\
\hline \multicolumn{9}{|l|}{ AMARANTHACEAE } \\
\hline Chenopodium amaranticolor & LLe;NLe & + & LLe;NLe & + & LLe;NLe & + & LLe;NLe & + \\
\hline C. quinoa & LLe;NLe & + & LLe;NLe & + & LLe;NLe & + & LLe;NLe & + \\
\hline Gomphrena globosa & $\mathrm{w} / \mathrm{s}$ & - & $\mathrm{w} / \mathrm{s}$ & - & $\mathrm{w} / \mathrm{s}$ & - & $\mathrm{w} / \mathrm{s}$ & - \\
\hline \multicolumn{9}{|l|}{ BRASSICACEAE } \\
\hline Brassica juncea & $\mathrm{w} / \mathrm{s}$ & - & $\mathrm{w} / \mathrm{s}$ & - & $\mathrm{w} / \mathrm{s}$ & - & $\mathrm{w} / \mathrm{s}$ & - \\
\hline \multicolumn{9}{|l|}{ CURCUBITACEAE } \\
\hline Cucumis sativum & $\mathrm{w} / \mathrm{s}$ & - & $\mathrm{w} / \mathrm{s}$ & - & $\mathrm{w} / \mathrm{s}$ & - & $\mathrm{w} / \mathrm{s}$ & - \\
\hline \multicolumn{9}{|l|}{ FABACEAE } \\
\hline Arachis hypogaea & $\mathrm{w} / \mathrm{s}$ & - & $\mathrm{w} / \mathrm{s}$ & - & $\mathrm{w} / \mathrm{s}$ & - & $\mathrm{w} / \mathrm{s}$ & - \\
\hline Canavalia ensiformis & $\mathrm{M}$ & + & $\mathrm{w} / \mathrm{s}$ & - & $\mathrm{M}$ & + & $\mathrm{M}$ & + \\
\hline Dolichos lablab & $\mathrm{w} / \mathrm{s}$ & - & $\mathrm{w} / \mathrm{s}$. & - & $\mathrm{w} / \mathrm{s}$. & - & $\mathrm{w} / \mathrm{s}$. & - \\
\hline Glycine $\max$ & $\mathrm{w} / \mathrm{s}$ & - & $\mathrm{w} / \mathrm{s}$ & - & $\mathrm{w} / \mathrm{s}$ & - & $\mathrm{w} / \mathrm{s}$ & - \\
\hline Leucaena leucocephala & $\mathrm{w} / \mathrm{s}$ & - & $\mathrm{w} / \mathrm{s}$ & - & $\mathrm{w} / \mathrm{s}$ & - & $\mathrm{w} / \mathrm{s}$ & - \\
\hline Macroptilium. atropurpureum & $\mathrm{w} / \mathrm{s}$ & - & $\mathrm{w} / \mathrm{s}$ & - & $\mathrm{w} / \mathrm{s}$ & - & $\mathrm{w} / \mathrm{s}$ & - \\
\hline M. lathyroides & SM; Bol & + & SM; Bol & + & SM; Bol & + & SM; Bol & + \\
\hline Pisum sativum & $\mathrm{mM}$ & + & $\mathrm{mM}$ & + & $\mathrm{mM}$ & + & $\mathrm{w} / \mathrm{s}$ & \\
\hline Vigna mungo & $\mathrm{w} / \mathrm{s}$ & - & $\mathrm{w} / \mathrm{s}$ & - & $\mathrm{w} / \mathrm{s}$ & - & $\mathrm{w} / \mathrm{s}$ & - \\
\hline \multicolumn{9}{|l|}{ V. unguiculata } \\
\hline Adzuki & $\mathrm{w} / \mathrm{s}$ & - & $\mathrm{w} / \mathrm{s}$ & - & $\mathrm{w} / \mathrm{s}$ & - & $\mathrm{w} / \mathrm{s}$ & - \\
\hline CE 113 & $\mathrm{w} / \mathrm{s}$ & - & $\mathrm{w} / \mathrm{s}$ & - & SM & + & SM & + \\
\hline CE 189 & $\mathrm{w} / \mathrm{s}$ & - & $\mathrm{w} / \mathrm{s}$ & - & SM & + & M & + \\
\hline CE 524 & $\mathrm{w} / \mathrm{s}$ & - & $\mathrm{w} / \mathrm{s}$ & - & SM & + & SM & + \\
\hline CE 566 & $\mathrm{w} / \mathrm{s}$ & - & $\mathrm{w} / \mathrm{s}$ & - & $\mathrm{M}$ & + & $\mathrm{M}$ & + \\
\hline Clay & $\mathrm{w} / \mathrm{s}$ & - & $\mathrm{w} / \mathrm{s}$ & - & SM & + & SM & + \\
\hline Costela-de-vaca & $\mathrm{w} / \mathrm{s}$ & - & $\mathrm{w} / \mathrm{s}$ & - & SM & + & $\mathrm{M}$ & + \\
\hline Lizão & $\mathrm{w} / \mathrm{s}$ & - & $\mathrm{w} / \mathrm{s}$ & - & SM & + & SM & + \\
\hline Macaibo & $\mathrm{w} / \mathrm{s}$ & - & $\mathrm{w} / \mathrm{s}$ & - & SM; Bol & + & SM; Bol & + \\
\hline Manteigão & $\mathrm{w} / \mathrm{s}$ & - & $\mathrm{w} / \mathrm{s}$ & - & $\mathrm{SM}$ & + & SM & + \\
\hline Paulista-PB & $\mathrm{w} / \mathrm{s}$ & - & $\mathrm{w} / \mathrm{s}$ & - & SM & + & $\mathrm{M}$ & + \\
\hline Paulistinha & $\mathrm{w} / \mathrm{s}$ & - & $\mathrm{w} / \mathrm{s}$ & - & SM & + & SM & + \\
\hline Pingo-de-ouro & $\mathrm{w} / \mathrm{s}$ & - & $\mathrm{w} / \mathrm{s}$ & - & SM & + & SM & + \\
\hline Pitiuba & $\mathrm{w} / \mathrm{s}$ & - & $\mathrm{w} / \mathrm{s}$ & - & SM; Bol, Ldef & + & SM; Bol, Ldef & + \\
\hline Sempre-verde & $\mathrm{w} / \mathrm{s}$ & - & $\mathrm{w} / \mathrm{s}$ & - & SM & + & SM & + \\
\hline Setentão & $\mathrm{w} / \mathrm{s}$ & - & $\mathrm{w} / \mathrm{s}$ & - & SM & + & SM & + \\
\hline \multicolumn{9}{|l|}{ LAMINACEAE } \\
\hline \multicolumn{9}{|l|}{ Ocimum basilicum } \\
\hline Basilicãovermelho & $\mathrm{w} / \mathrm{s}$ & - & $\mathrm{w} / \mathrm{s}$ & - & $\mathrm{w} / \mathrm{s}$ & - & $\mathrm{w} / \mathrm{s}$ & - \\
\hline Lemoncio & $\mathrm{w} / \mathrm{s}$ & - & $\mathrm{w} / \mathrm{s}$ & - & $\mathrm{w} / \mathrm{s}$ & - & $\mathrm{w} / \mathrm{s}$ & - \\
\hline Toscano & $\mathrm{w} / \mathrm{s}$ & + & $\mathrm{w} / \mathrm{s}$ & + & $\mathrm{w} / \mathrm{s}$ & + & $\mathrm{w} / \mathrm{s}$ & + \\
\hline
\end{tabular}


Table 1 Continued

\begin{tabular}{|c|c|c|c|c|c|c|c|c|}
\hline Passiflora edulis & SM & + & $\mathrm{mM}$ & + & $\mathrm{w} / \mathrm{s}$ & - & $\mathrm{w} / \mathrm{s}$ & - \\
\hline P. edulis 'Macae' & SM & + & $\mathrm{mM}$ & + & $\mathrm{w} / \mathrm{s}$ & - & $\mathrm{w} / \mathrm{s}$ & - \\
\hline P. setacea & SM & + & $\mathrm{mM}$ & + & $\mathrm{w} / \mathrm{s}$ & - & $\mathrm{w} / \mathrm{s}$ & - \\
\hline P. cincinnata & SM & + & $\mathrm{mM}$ & + & $\mathrm{w} / \mathrm{s}$ & - & $\mathrm{w} / \mathrm{s}$ & - \\
\hline P. gibertii & SM & + & $\mathrm{mM}$ & + & $\mathrm{w} / \mathrm{s}$ & - & $\mathrm{w} / \mathrm{s}$ & - \\
\hline \multicolumn{9}{|l|}{ PEDALIACEAE } \\
\hline Sesamum indicum & M & + & M & + & $\mathrm{M}$ & + & M & + \\
\hline \multicolumn{9}{|l|}{ SOLANACEAE } \\
\hline Nicotiana benthamiana & $\mathrm{mM}$ & + & $\mathrm{mM}$ & + & $\mathrm{w} / \mathrm{s}$ & - & $\mathrm{w} / \mathrm{s}$ & - \\
\hline N. debneyi & $\mathrm{w} / \mathrm{s}$ & - & $\mathrm{w} / \mathrm{s}$ & - & $\mathrm{w} / \mathrm{s}$ & - & $\mathrm{w} / \mathrm{s}$ & - \\
\hline Petunia axillaris & $\mathrm{w} / \mathrm{s}$ & - & $\mathrm{w} / \mathrm{s}$ & - & $\mathrm{w} / \mathrm{s}$ & - & $\mathrm{w} / \mathrm{s}$ & - \\
\hline
\end{tabular}

*Bol: bubles; Ldef: leaf deformations; LLe: local lesions; NLe: necrotic lesions; mM: mild mosaic; SM: severe mosaic; w/s: without symptoms

Biological Interactions among Isolates of Cowpea aphid-borne mosaic virus Obtained from Cowpea and from Passion Fruit

The cross protection experiments in passion fruit, demonstrated that the mild virus isolate obtained from passion fruit (CABMV-PMild) did not protect passion fruit plants against the severe virus isolate (CABMVPSevere). Passion fruit plants inoculated with CABMVPMild and 15 days later inoculated with CABMV-PSevere developed severe symptoms (Figure 2), indicating the presence of CABMV-PSevere. This was confirmed by inoculation into $C$. ensiformis, which is not infected by CABMV-PMild (Table 1), but developed symptoms and tested positively for CABMV-PSevere by PTA-ELISA. These results demonstrated the absence of cross protection between these two virus isolates probably due to the low level of CABMV-PMild replication in passion fruit when compared with CABMV-PSevere replication level.

Figure 2 - Plants of Passiflora edullis inoculated with a mild strain of Cowpea aphid-borne mosaic virus (CABMV) isolated from P. edulis (CABMV-PMild) and later inoculated with a severe strain also isolated from $P$. edulis (CABMVPSevere) showing severe symptoms

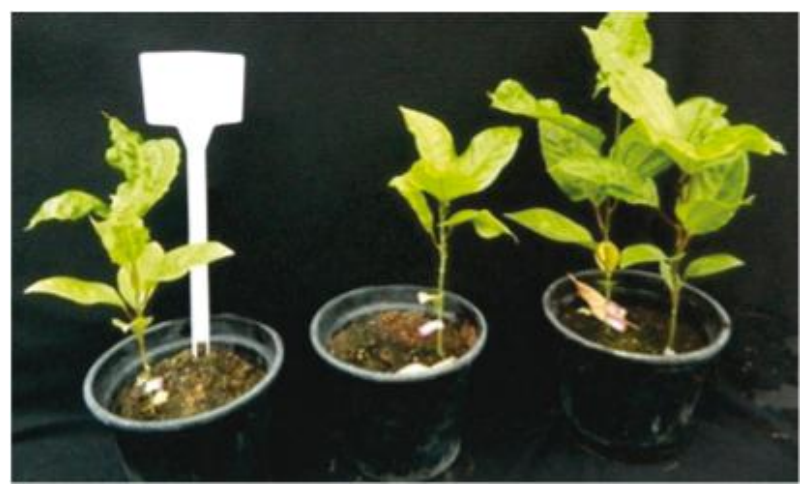

The interaction studies between CABMV-CFor and CABMV-PSevere also provided evidence for the absence of cross protection in C. ensiformis. Plants of C. ensiformis inoculated with CABMV-CFor and super inoculated with CABMV-PSevere 15 days later showed more severe symptoms than those shown by plants inoculated only with CABMV-CFor. Additionally, extracts from doubly inoculated $C$. ensiformis plants caused infections in cowpea as well as in passion fruit plants, which exhibited virus symptoms. The presence of CABMV-PSevere in inoculated $C$. ensiformis was also confirmed by PTAELISA.

C. ensiformis plants inoculated with CABMVPSevere and after 15 days super inoculated with CABMV-CFor did not present stronger symptoms, when compared with plants inoculated only with CABMVPSevere. Cowpea plants inoculated with extracts from the doubly inoculated C. ensiformis plants were not infected, evidencing the absence of CABMV-CFor in the doubly inoculated $C$. ensiformis plants with CABMV-PSevere and $\mathrm{CABMV-CFor.} \mathrm{Those} \mathrm{results} \mathrm{provide} \mathrm{good} \mathrm{evidence}$ of cross protection of CABMV-PSevere against CABMVCFor in $C$. ensiformis, confirming unilateral cross protection between those virus isolates in function of the host plant used. However, passion fruit plants inoculated with extracts from $C$. ensiformis doubly inoculated with CABMV-PSevere and CABMV-CFor showed symptoms (Figure 3) indicating the presence of CABMV-PSevere which was confirmed by PTA-ELISA.

The absence of cross protection between CABMV-PMild and CABMV-PSevere is an indication that this mild strain (CABMV-PMild) is not recommended to be used as a biological control for woodiness disease in passion fruit. The absence of cross protection was probably due to the low level of CABMV-PMild replication in passion fruit when 
Figure 3 - Canavalia ensiformis plant inoculated with a severe strain of Cowpea aphid-borne mosaic virus (CABMV) obtained from naturally infected Passiflora edulis(CABMVPSevere)

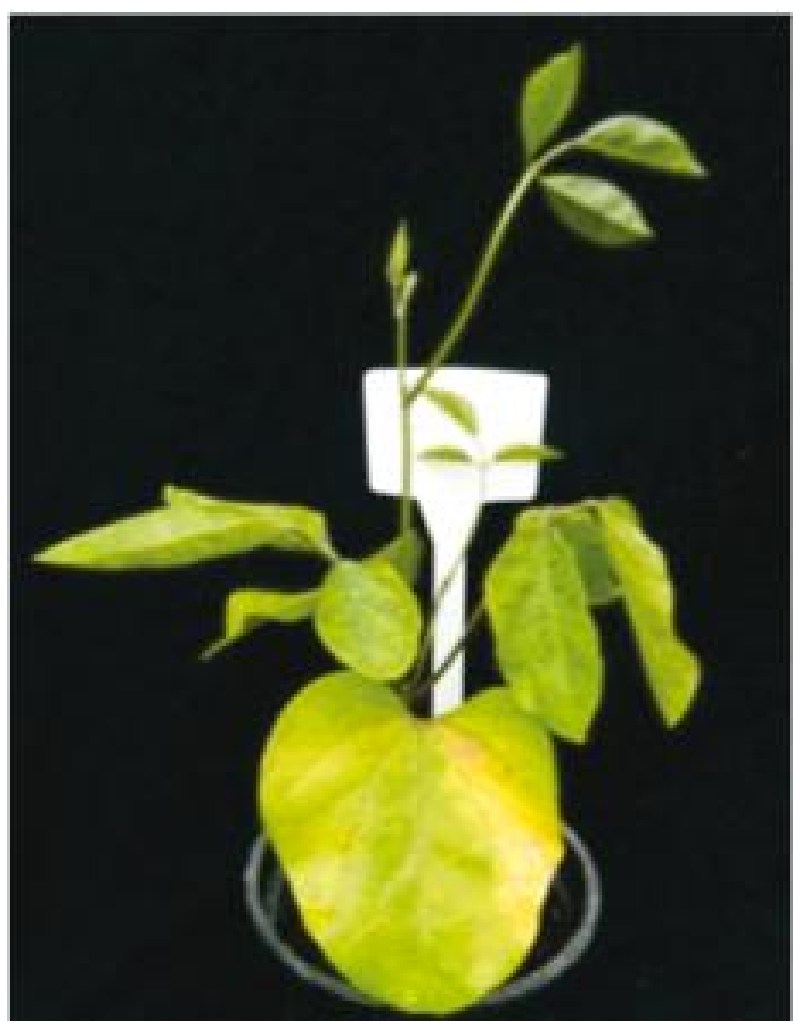

compared with the CABMV-PSevere replication level. Novaes and Rezende (2003) also observed the lack of cross protection between mild and severe strains of virus from the genus Potyvirus in passion fruit plants and attributed the absence of cross protection to apparent differences in the distribution of the mild virus strain and the possible low concentration of it in the infected tissues. The low concentration of mild virus strain in infected tissues will leave clusters of uninfected cells permitting the replication and establishment of the severe strain. Nevertheless, cross protection has been commonly observed between other virus strains (NOVAES; REZENDE, 2003; LIMA et al., 2015).

Besides being an alternative to control of plant viruses in the field, the cross protection phenomenon constitutes a biological criterion for strain definition and identification inside of virus species, especially with those from the genus Potyvirus. Associated to cross protection criterion between virus strains, the identity of nucleotide sequences from the coat protein gene $(c p)$ and the non translated 3 region of the virus genome are biological and molecular parameters of great value for identification of virus species in the family Potyviridae (VAN REGENMORTEL et al., 2000).

The unilateral cross protection observed between CABMV-PSevere and CABMV-CFor represents a good evidence of the close relationship between these two virus isolates, which was confirmed by serological and molecular studies (NASCIMENTO, 2014).

\section{CONCLUSIONS}

1. The isolates of Cowpea aphid-borne mosaic virus (CABMV) obtained from passion fruit (CABMV-P) do not infect cowpea and the CABMV isolates obtained from cowpea (CABMV-C) do not infect passion fruit;

2. The CABMV obtained from cowpea (CABMV-C) area biologically different from the isolates of CABMV obtained from passion fruit (CABMV-P);

3. The mild strain of CABMV obtained from passion fruit (CABMV-PMild) did not cross protect passion fruit against the severe strain (CABMV-PSevere);

4. The mild strain (CABMV-PMild) obtained from passion fruit is not recommended to be used as a biological control for woodiness disease;

5. Unilateral cross protection can be observed between CABMV-PSevere and CABMV-CFor, depending on the host.

\section{REFERENCES}

BARROS, G. B. et al. Obtenção de plantas de feijão-caupi resistentes ao Cowpea severe mosaic virus e ao Cowpea aphid-borne mosaic virus. Summa Phytopathologica, v. 39, n. 2, p. 130- 136, 2013.

BOCK, K. R. East African strains of Cowpea aphid-borne mosaic virus. Annals of Applied Biology, v. 74, n. 1, p. 7583, 1973.

FISCHER, I. H.; KIMATI, H.; REZENDE, J. A. M. Doenças do maracujazeiro: (Passiflora spp.). In: KIMATI, H.; AMORIM, L.; REZENDE, J. A. M.; BERGAMIM FILHO, A.; CAMARGO, L. E. A. Manual de fitopatologia: doenças das plantas cultivadas. 4. ed., São Paulo: Agronômica Ceres, 2005. v. 2.

LIMA , J. A. A.; SILVEIRA, L. F. S.; SANTOS, C. D. G. Infecção natural em gergelim ocasionada por um potyvirus. Fitopatologia Brasileira. 1991. V.16: p 60-62.

LIMA, J. A. A. et al. Etiologia, sintomatologia, distribuição geográfica e estratégias de controle de viroses em culturais tropicais. In: LIMA, J. A. A. Virologia essencial \& viroses em culturas tropicais. 1. ed. Fortaleza: Edições UFC, 2015, cap. 9-15, p. 303-527. 
MACIEL, S. C. et al. Screening of Passiflora species for reaction to Cowpea aphid-borne mosaic virus reveals an immune wild species. Scientia Agrícola, v. 66, n. 3, p. 414-418, 2009.

NASCIMENTO, A. K. Q. Inovações tecnológicas para diagnose de viroses de plantas e caracterização de biótipos de Cowpea aphid-borne mosaic virus. 2014. 135 f. Tese (Doutorado em Fitotecnia) - Centro de Ciências Agrárias, Universidade Federal do Ceará, Fortaleza, 2014.

NASCIMENTO, A. V. S. et al. Cowpea aphid-borne mosaic virus (CABMV) is widespread in passion fruit in Brazil and causes passion fruit woodiness disease. Archives of Virology, v. 151, n. 9, p. 1797-1809, 2006.

NICOLINI, C. et al. Possible host adaptation as an evolution factor of Cowpea aphid-borne mosaic virus deduced by coat protein gene analysis. Journal of Phytopathology, v. 160, n. 2, p. 82-87, 2012.

NOVAES, Q. S.; REZENDE, J. A. M. Selected mild strains of Passion fruit woodiness virus (PWV) fail to protect pre-immunized vines in Brazil. Scientia Agricola, v. 60, p. 699-708. 2003.
RODRIGUES, L. K. et al. Phylogeny and recombination analysis of Brazilian yellow passion fruit isolates of Cowpea aphid-borne mosaic virus: origin and relationship with hosts. Australasian Plant Pathology, v. 44, n. 1, p. 31-41, 2015.

SISTEMA IBGE DE RECUPERAÇÃO AUTOMÁTICA. Banco de dados agregados. 2015. Disponível em: <http:// www.sidra.ibge.gov.br/bda/agric/ default.asp?t=2\&z=t\&o=1 $1 \& u 1=1 \& u 3=1 \& u 4=u 5=1 \& u 6=1 \& u 2=19>$. Acesso em: 14 jul. 2015.

SREENIVASULU, P. et al. A potyvirus causing mosaic disease of sesame (Sesamum indicum). Plant Disease, v. 78, p. 95-99, 1994.

TAIWO, M. A.; AKINJOGUNLA, O. J. Cowpea viruses: quantitative and qualitative effects of single and mixed viral infections. African Journal of Biotechnology, v. 5, n. 19, p. 1749-1756, 2006.

VAN REGENMORTEL, M. H. V. et al. Virus taxonomy: seventh report of the International Committee on the Taxonomy of Viruses. 1. ed. New York : Academic Press, 2000. 1121 p. 